\title{
PENGARUH DUKUNGAN KELUARGA TERHADAP MOTIVASI UNTUK SEMBUH PADA PASIEN TB PARU DI PUSKESMAS KRAMAT JATI JAKARTA TIMUR
}

\author{
Nurma Dewi \\ Program studi DIII Keperawatan Universitas MH Thamrin
}

\begin{abstract}
ABSTRAK
Tuberculosis paru merupakan suatu penyakit infeksi yang menular dan disebabkan oleh kuman TB (mycobacterium tuberculosis). penyakit TB paru dapat diderita oleh siapa saja, orang dewasa atau anak-anak dan dapat mengenai seluruh organ tubuh kita manapun, walaupun yang terbanyak adalah organ paru. dukungan keluarga merupakan salah satu pengaruh dalam memotivasi pasien TB paru untuk cepat sembuh dari penyakit. tujuan dari penelitian ini adalah teridentifikasinya hubungan dukungan keluarga terhadap motivasi untuk sembuh pada penderita TB paru di puskesmas kramat jati. penelitian ini merupakan penelitian kuantitatif dengan menggunakan desin deskriptif analitik dengan pendekatan cross-sectional. jumlah sampel 55 responden dipilih dengan menggunakan teknik non probability sampling melalui tekhnik convinent sampling. hasil analisis menggunakan korelasi uji chi square menunjukan tidak ada pengaruh dukungan keluarga terhadap motivasi ( $\mathrm{p}$ value $=0,886$, alpha $=0,10$ ). variabel confounding terhadap pengaruh motivasi untuk sembuh pada pasien TB paru adalah umur didapatkan nilai $p$ value $=0,01$ pada alpha $5 \%$, jenis kelamin nilai $p$ value $=0,471$, tingkat pendidikan didapatkan nilai $\mathrm{p}$ value $=0,001$ dan pekerjaan didapatkan nilai $\mathrm{p}$ value $=0,03$. berdasarkan hal tersebut perlu meningkatkan motivasi intrinsik pasien dengan membangun kesadaran untuk berobat.petugas kesehatan agar melakukan penyuluhan tentang pentingnya pengobatan untuk memotivasi pasien agar cepat sembuh serta lebih mengaktifkan peran PMO.
\end{abstract}

Kata Kunci : Dukungan Keluarga, Motivasi Sembuh, umur, pekerjaan

\section{PENDAHULUAN}

Tubercolusis (TB) merupakan suatu penyakit infeksi yang menular dan disebabkan oleh kuman TB (mycobacterium tuberkulosis). Penyakit TB dapat diderita oleh siapa saja, orang dewasa atau anak-anak dan dapat mengenai seluruh organ tubuh kita manapun, walaupun yang terbanyak adalah organ paru (Yahmin, 2013).

Pada umumnya penyakit TB menular melalui udara, dan biasanya bakteri mycobacterium tuberculosa terbawa pada saat seseorang batuk lalu mengeluarkan dahak. Bahayanya jika bakteri selalu masuk dan terkumpul dalam paru-paru, maka bakteri ini akan berkembang biak dengan cepat apalagi yang mempunyai daya tahan tubuh yang rendah. Apabila sudah terjadi infeksi maka dengan mudahnya akan menyebar melalui pembuluh darah atau kelenjar getah bening. Terjadinya infeksi TB dapat mempengaruhi organ tubuh lainnya (Yahmin, 2013).

Bakteri mycobacterium tuberculosa mempunyai bentuk seperti batang dan bersifat seperti tahan asam sehingga dikenal sebagai bta (batang tahan asam) yang merupakan faktor utama penyakit TB. Selain dari bakteri tersebut, faktor yang lain yang menjadi penyebab penyakit TB adalah lingkungan yang lembab, kurang sirkulasi udara, dan kurangnya sinar matahari dalam ruangan sangat berperan terjadinya penyebab bakteri mycobacterium tuberculosa ini. Dengan demikian sangat mudah menyerang orang-orang disekitar dalam kondisi lingkungan yang kurang sehat (Yahmin, 2013).

Sampai saat ini, belum ada satu negara pun yang bebas TB. Angka kematian dan kesakitan akibat kuman TB di dunia ini pun tinggi. Pada tahun 2009, di dunia terdapat 1,7 juta orang meninggal karena TB (600.000 diantaranya perempuan) sementara ada 9,4 juta kasus baru TB (3,3 juta diantaranya perempuan). Sepertiga dari 
populasi dunia sudah tertular dengan TB dimana sebagian besar penderita TB adalah usia produktif (15-55 tahun) (Yahmin, 2013).

Menurut global tuberculosis control : WHO report 2010, kasus tuberkulosis (TB) di indonesia pernah mengalami penurunan. Saat itu indonesia berada di urutan kelima (setelah india, china, afrika selatan dan nigeria) setelah selama sepuluh tahun terakhir menempati urutan ketiga (setelah india dan china) sebagai negara dengan kasus TB terbesar di dunia. Tapi saat ini indonesia di urutan 4 dunia, didapat data TB indonesia, total seluruh kasus TB tahun 2009 sebanyak 294731 kasus, dimana 169213 adalah kasus TB baru bta positif, 108616 adalah kasus TB bta negatif, 11215 adalah kasus TB extra paru, 3709 adalah kasus TB kambuh, dan 1978 adalah kasus pengobatan ulang diluar kasus kambuh. Sementara itu menururt Kementrian Kesehatan tahun 2017 memprediksi sebanyak 1.020 .000 orang terinfeksi TB namun data yang terlapor baru sebesar 420.000 kasus.

Ada beberapa faktor yang menyebabkan tingginya kasus TB di indonesia. Pertama, waktu pengobatan TB yang relatif lama ( $6-8$ bulan) menjadi penyebab pasien TB sulit sembuh karena pasien TB berhenti berobat (drop) setelah merasa sehat meski proses pengobatan belum selesai. Kedua,masalah TB diperberat dengan adanya peningkatan infeksi hiv/aids yang berkembang cepat dan munculnya permasalahan TB-mdr (multi drugs resistant $=$ kebal terhadap bermacam obat). Dan ketiga adalah adanya penderita TB laten, dimana penderita tidak sakit namun akibat daya tahan tubuh menurun, penyakit TB akan muncul (setiawan, 2013). Kemungkinan faktor lain yang dapat menyebabkan tingginya kasus TB yaitu kurangnya pengetahuan pasien tentang penularan TB terhadap orang lain terutama adalah keluarga. Karena resiko penularan tergantung dari tingkat pajanan dengan percikan dahak. Pasien TB paru dengan bta positif memberikan kemungkinan resiko penularan lebih besar dari pasien TB paru dengan bta negatif (Depkes RI, 2009).

Menurut rachmawati (2009) dari 89 responden yang diambil dari 10 puskesmas di 3 (tiga) kabupaten yaitu sidoarjo, lamongan, dan jombang. Lebih banyak laki-laki (52,3\%) sedangkan perempuan yaitu sekitar 47,7\%. Umur responden sangat bervariasi, yang termuda 9 tahun dan yang tertua berusia 78 tahun yaitu masing-masing satu orang. Kelompok umur terbanyak 29,4\% yaitu antara 36-45 tahun. Dan bila dilihat secara keseluruhan penderita TB terbanyak pada umur antara 16-45 tahun, dimana merupakan usia produktif. Tetapi juga cukup banyak $14,1 \%$ penderita lanjut usia lebih dari 55 tahun. Hal ini dipahami karena semakin lanjut usia semakin rentan terhadap penyait ini.

Berdasarkan penjelasan diatas perlu dipikirkan untuk mengenal terjadinya kasus TB paru, maka dibutuhkan peran perawat dalam menjelaskan pada pasien tentang pentingnya berobat secara teratur sesusai dengan jadwal sampai sembuh. Selain itu dukungan social dan dukungan dari keluarga sangatlah penting untuk pengobatan dan kesembuhan pada pasien TB paru. Inilah cara menyembuhkan penderita dan memutuskan rantai penularan. Selain itu, usaha pencegahan dan menemukan penderita secara aktif seharusnya juga perlu lebih ditingkatkan dalam rangka memutuskan rantai penularan.

Keluarga dapat menjadi faktor yang sangat berpengaruh dalam menentukan keyakinan dan nilai kesehatan individu serta dapat juga menentukan tentang program pengobatan yang dapat mereka terima. Keluarga juga memberikan dukungan dan membuat keputusan mengenai perawatan dari anggota keluarga yang sakit (niven, 2002). 
Dukungan keluarga sangat berperan dalam rangka meningkatkan kepatuhan minum obat. Keluarga adalah unit terdekat dengan pasien dan merupakan motivator terbesar dalam perilaku pencapaian kesembuhan penyakit TB paru. Sampai saat ini belum ada data yang pasti tentang bobot pengaruh dukungan keluarga yang diperlukan pasien TB paru dalam hal ini adalah sikap, tindakan dan penerimaan keluarga terhadap anggota keluarga yang sakit. Menurut friedman (2010), keluarga memandang bahwa orang yang bersifat mendukung selalu siap memberikan dukungan agar pasien rutin dalam pengobatan. Adanya perhatian dan dukungan keluarga dalam mengawasi dan mengingatkan penderita untuk minum obat dapat mempercepat kesembuhan dan memperbaiki derajat kesehatan penderita TB paru itu sendiri.

Menurut hutapea (2006) pada 134 responden di pemberantasan penyakit paru (bp4) atau rs karangtembok surabaya yang menunjukan adanya hubungan antara dukungan keluarga dapat meningkatkan kepatuhan minum oat peasien TB paru ( $p$ value $=0,001)$.

Motivasi merupakan satu penggerak dari dalam hati seseorang untuk melakukan atau mencapai sesuatu tujuan. Motivasi juga bisa dikatakan sebagai rencana atau keinginan untuk menuju kesuksesan dan menghindari kegagalan hidup. Dengan kata lain motivasi adalah sebuah proses untuk tercapainya suatu tujuan. Seseorang yang mempunyai motivasi berarti ia telah mempunyai kekuatan untuk memperoleh kesuksesan dalam kehidupan. Teori maslow mengasumsikan bahwa orang berusaha memenuhi kebutuhan yang lebih mendasar sebelum mengarahkan perilakunya untuk memenuhi kebutuhan yang lebih tinggi. Asumsi lain ialah orang mempunyai keinginan untuk maju sehingga setelah kebutuhan yang lebih rendah terpenuhi maka orang tersebut akan bergerak memenuhi kebutuhan yang lebihtinggi.

Berdasarkan hasil wawancara yang dilakukan pada petugas kesehatan puskesmas kramat jati, ada beberapa kendala yang dihadapi oleh petugas kesehatan dalam penanganan kasus $\mathrm{TB}$, diantaranya yaitu beberapa pasien sering telat mengambil obat, dan apabila mengambil obat penderita TB jarang diantar oleh keluarga tapi mengambil sendiri, sehingga menimbulkan ketidakpatuhan minum obat TB.

Indonesia sekarang berada pada peringkat kelima negara dengan beban TB paru tertinggi didunia.Estimasi prevalensi TB semua kasus adalah sebesar 660.000 (who, 2010) dan estimasi insidensi berjumlah 430.000 kasus baru per tahun.Jumlah kematian akibat TB diperkirakan 61.000 kematian pertahunnya. Sedangkan angka mdrTB diperkirakan sebesar 2\% dari seluruh kasus TB baru (lebih rendah dari estimasi regional sebesar 4\%), dalam $20 \%$ dari kasus TB dengan pengobatan ulang diperkirakan terdapat sekitar 6.300 kasus mdr-TB disetiap tahunnya (strategi nasional pengendalian TB di indonesia, 2014 ).

Dari data dinas Kesehatan Provinsi DKI Jakarta diketahui jumlah penduduk jakarta pada tahun 2016 sekitar 10,09 juta jiwa dengan angka harapan hidup 74,0 tahun, angka ini sudah meningkat dari tahun 2011 yang tercatat bahwa angka harapan hidup 73,5 tahun. Namun demikian tidak dengan angka penderita TB paru, pada tahun 2015 tercatat penderita TB paru suspek sebanyak 55.503 orang, dari jumlah itu yang positif diagnosa TB Paru sebanyak 5.574 penderita baru, sementara pada tahun 2016 yang terdiagnosa positif sebanyak 7.302 penderita baru dan dari 7.302 penderita yang berhasil sembuh sebanyak 80,59\% dengan angka kesembuhan sebanyak 80,59\%, dan angka kesembuhan terbesar berada di Kota Administrasi Jakarta Timur (Salama,2017)

Kota Administrasi Jakarta Timur memiliki sekitar 10 Kecamatan yang kesemuanya memiliki beban penderita TB Paru. Dari 10 kecamatan tersebut Kecamatan Kramat Jati Merupakan kecamatan dengan jumlah 
beban penderita TB paling banyak yaitu 2.539 penderita dengan angka MDR minimal 51 orang, kemudian disusul Kecamatan Cakung dengan 1.199 penderita dan urutan ketiga Kecamatan Jatinegara dengan jumlah penderita 1.121 orang. (Salama Ngabila, 2017). Penyakit TB paru merupakan penyakit kronis yang berdampak luas pada semua aspek kehidupan. dampak tersebut biasanya berpengaruh pada kondisi fisik, psikologis dan sosial. hal ini akan semakin memperburuk rendahnya dukungan keluarga dan akhirnya akan berpengaruh terhadap motivasi untuk sembuh pada paien TB paru. serta masih tingginya angka kasus tb di dunia. indonesia sekarang berada pada ranking keempa negara dengan beban TB tertinggi didunia. estimasi prevalensi TB semua kasus adalah sebesar 660,000 (WHO, 2010) dan estimasi insidensi berjumlah 430,000 kasus baru per tahun. jumlah kematian akibat tb diperkirakan 61,000 kematian per tahunnya (Depkes,2011).

Pasien dengan TB paru cenderung mempunyai harapan yang rendah terhadap kesembuhannya sendiri dan putus asa terhadap pengobatannya sehingga mengakibatkan putus obat, hal ini kemungkinan disebabkan oleh terlalu lamanya pengobatan dan bosan minum obat, keluarga tidak memperhatikan kondisi pasien yang menderita TB paru dan stigma yang negatif terhadap pasien TB paru pada masyarakat. Oleh karena itu peneliti tertarik untuk meneliti lebih lanjut tentang "bagaimana pengaruh dukungan keluarga terhadap motivasi untuk sembuh pada pasien TB paru di puskesmas kramat jati”.Tujuan umum dari penelitian ini adalah teridentifikasinya pengaruh dukungan keluarga terhadap motivasi untuk sembuh pada penderita TB paru di Puskesmas Kramat Jati.

\section{METODE}

Penelitian ini merupakan penelitian kuantitatif dengan menggunakan desain deskriptif analitik dengan pendekatan cross-sectional, dengan variabel dependen (motivasi untuk sembuh pada penderita TB paru), pengumpulan data pada satu waktu dengan menggunakan alat ukur berupa kuisioner.

Populasi dan Sampel

Populasi dalam penelitian ini adalah pasien TB paru positif yang sedang menjalani pengobatan TB di Puskesmas Kramat Jati.Tehnik sampling yang digunakan dalam penelitian ini dengan metode non probability sampling (sample non random) melalui tehnik convinent sampling.

Sampel dalam penelitian adalah pasien TB paru yang sedang menjalani berobat jalan pada bulan September - Desember 2017 di Puskesmas Kramat Jati Jakarta Timur. Adapun kriteria yang dimaksud dari penelitian ini adalah sebagai berikut:

1. Kriteria inklusi

a. Responden menderita TB paru aktif yang sedang menjalani berobat jalan di Puskesmas Kramat Jatai Jakarta Timur.

b. Usia minimal 20 tahun

c. Keadaan komposmentis

d. Dapat berkomunikasi denganbaik

e. Mampu membaca dan menulis

f. Bersedia menjadi responden penelitian dankooperatif 
2. Kriteria eksklusi

a. Pasien atau keluarga menolak untuk menandatangani informedconsent

b. Pasien TB paru mengalami ketidaknyamanan fisik yang berat seperti sesak yang sangat, demam tinggi, atau kelelahan ekstrim sehingga tidak memungkinkan untuk responden mengikutipenelitian.

Besaran sampel yang dibutuhkan dalam penelitian ini, sesuai dengan rumus sampel (Nursalam, 2011)

$\mathrm{n}=$ jumlah sampel

$\mathrm{N}=$ Jumlah populasi yang diketahui (123)

$\mathrm{d}=$ Tingkat kepercayaan yang diinginkan $(10 \%)$

$$
\mathrm{n}=\frac{\mathrm{N}}{N d^{2}+1}
$$

Maka besaran jumlah sampel dalam penelitian ini adalah $=55$ responden

\section{Waktu Dan Tempat Penelitian}

Penelitian dilakukan di Puskesmas Kramat Jati Jakarta Timur. Pemilihan tempat ini karena Puskesmas Kramat Jati merupakan rujukan dari Puskesmas yang ada di wilayah Kecamatan Kramat Jati dan merupakan salah satu daerah binaan dari Universitas MH Thamrin, selain itu di Puskesmas Kramat Jati sudah mempunyai petugas khusus yang menangani TB paru. Puskesmas Kramat Jati merupakan Puskesmas yang digunakan untuk sarana praktik dan pendidikan sehingga sangat mungkin untuk melakukan penelitian.Penelitian ini dimulai dari persiapan pembuatan proposal yang dimulai sejak Oktober 2017, pengambilan data bulan November-Desember serta analisis data dilaksanakan mulai Desember sampai dengan bulan Januari 2018

Analisis Data

Setelah dilakukan pengolahan data langkah selanjutnya adalah analisis data. Analisis data yang dilakukan meliputi analisis data univariat, analisa univariat dilihat dari nilai sentral (mean, median atau presentase) maupun dari nilai sebarannya. Analisis bivariat mengunakan rumus uji chi square dan keeratan hubungan.

\section{HASIL DAN PEMBAHASAN}

\section{Analisis Univariat}

Pada penelitian ini hasil analisis univariat menggambarkan distribusi responden berdasarkan karakteristik pasien TB paru dan berdasarkan data demografi yaitu : umur, jenis kelamin, tingkat pendidikan dan pekerjaan.

1. Gambaran karaktersitik responden berdasarkan usia

Tabel 1

Distribusi responden TB paru berdasarkan karakteristik respoden Di Puskesmas Kramat Jati

\begin{tabular}{cccc}
\hline Variabel & Kategori & Jumlah & Presentase \\
\hline Usia & Dewasa & 44 & 80 \\
& Lansia & 11 & 20 \\
\hline Jenis kelamin & Laki-laki & 32 & 58,2 \\
& Perempuan & 23 & 41,8 \\
\hline Tingkat & Rendah & 46 & 83,6 \\
Pendidikan & Tinggi & 9 & 16,4 \\
\hline Pekerjaan & Tidak bekerja & 23 & 41,8 \\
& Bekerja & 32 & 58,2
\end{tabular}

Tabel 1 menggambarkan responden TB paru di Puskesmas Kramat Jati berdasarkan usia sebagian besar adalah dewasa yaitu berjumlah 44 responden (80\%) sedangkan Lansia berjumlah 11 responden (20\%). Berdasarkan jenis kelamin sebagian besar adalah laki-laki dengan jumlah 32 responden $(58,2 \%)$ sedangkan 
perempuan berjumlah 23 responden (41,8\%). Berdasarkan tingkat pendidikan sebagian besar adalah berpendidikan rendah yaitu berjumlah 46 responden $(83,6 \%)$ sedangkan berpendidikan tinggi berjumlah 9 responden (16,4\%). Berdasarkan pekerjaan sebagian besar adalah bekerja yaitu berjumlah 32 responden $(58,2 \%)$ sedangkan tidak bekerja berjumlah 23 responden $(41,8 \%)$.

2. Variabel motivasi untuk sembuh, variabel dukungan keluarga

Tabel 2

Distribusi Responden TB Paru Di Puskesmas Kramat Jati, Berdasarkan Motivasi Untuk Sembuh Dan Dukungan Keluarga

\begin{tabular}{cccc}
\hline Variabel & Kategori & Jumlah & Presentase \\
\hline Motivasi untuk sembuh & Tidak baik & 2 & 3,6 \\
& Baik & 53 & 96,4 \\
\hline Dukungan keluarga & Tidak baik & 18 & 32,7 \\
& Baik & 37 & 67,3 \\
\hline
\end{tabular}

Tabel 2 menggambarkan responden TB paru di Puskesmas Kramat Jati berdasarkan motivasi untuk sembuh sebagian besar adalah motivasinya baik yaitu berjumlah 53 responden $(96,4 \%)$ sedangkan tidak baik berjumlah 2 responden (3,6\%). Berdasarkan dukungan keluarga sebagian besar adalah baik yaitu berjumlah 37 responden $(67,3 \%)$ sedangkan tidak baik berjumlah responden 18 responden $(32,7 \%)$.

\section{Analisa Bivariat}

Analisis bivariat digunakan untuk mengetahui apakah ada hubungan yang signifikan antara motivasi untuk sembuh dengan karakteristik umur, jenis kelamin, tingkat pendidikan dan pekerjaan pada pasien TB paru, dan untuk mengetahui hubungan antara dukungan keluarga dengan motivasi untuk sembuh pada pasien TB paru di Puskesmas Kramat Jati. Adapun uji yang digunakan adalah uji Chi Square dan Keterikatan.

1. Analisa pengaruh dukungan keluarga terhadap motivasi untuk sembuh.

Hasil analisis pengaruh dukungan keluarga terhadap motivasi untuk sembuh pada tabel 3 memperlihatkan bahwa sebanyak 23 responden $(63,9 \%)$ dukungan keluarga yang tidak baik dan motivasi untuk sembuh yang tidak baik. Sedangkan responden yang memiliki dukungan keluarga yang tidak baik dengan motivasi untuk sembuh yang baik sebanyak 13 responden (36,1\%). Hasil uji statistik didapatkan nilai $\mathrm{p}$ value $=0,886$ pada alpha $5 \%$, maka dapat disimpulkan bahwa tidak ada pengaruh dukungan keluarga terhadap motivasi untuk sembuh pada pasien TB paru. Hal ini sesuai dengan penelitian Rahmawati (2009) menyatakan bahwa ada efek langsung dukungan keluarga terhadap motivasi untuk sembuh pada pasien TB paru.

Menurut Suhardi (2013) menyatakan bahwa dukungan sosial dan keluarga merupakan sebagai informasi verbal dan non verbal, sarana, bantuan, yang nyata atau tingkah laku yang diberikan orang-orang yang akrab dengan subyek di dalam lingkungan sosialnya atau yang berupa kehadiran dan halhal yang dapat memberikan keuntungan emosional atau tingkah laku penerima. Dukungan sosial sangat berpengaruh dalam memotivasi untuk sembuh. Tapi hal ini tidak sesuai dengan penelitian yang saya lakukan bahwa tidak ada hubungan dukungan keluarga dengan motivasi untuk sembuh. Ketidakbermaknaan hasil ini dimungkinkan karena faktor internal yang sangat berpengaruh pada individu yang ingin cepat 
sembuh dari berbagai penyakit terutama TB paru.

Tabel 3

Distribusi responden menurut motivasi untuk sembuh, karakteristik dan dukungan keluarga pada pasien TB paru di Puskesmas Kramat Jati tahun 2017 ( $\mathrm{N}=55)$

\begin{tabular}{|c|c|c|c|c|c|c|c|c|}
\hline \multirow{3}{*}{$\begin{array}{c}\text { Variabel } \\
\text { Independen }\end{array}$} & \multirow[b]{3}{*}{$\mathbf{N}$} & \multirow{2}{*}{$\frac{\text { Motivasi }}{\text { Tidak }}$} & \multirow{2}{*}{\multicolumn{2}{|c|}{$\frac{\text { untuk Sembuh }}{\text { Baik }}$}} & \multicolumn{2}{|c|}{ Total } & \multicolumn{2}{|c|}{ OR $(95 \% P$} \\
\hline & & & & & & & \multirow[t]{2}{*}{ CI) } & \multirow[t]{2}{*}{ Value } \\
\hline & & $\%$ & $\mathbf{N}$ & $\%$ & $\mathbf{N}$ & $\%$ & & \\
\hline \multicolumn{9}{|l|}{$\begin{array}{l}\text { Dukungan } \\
\text { Keluarga }\end{array}$} \\
\hline Tidak baik & 23 & 63,9 & 13 & 36,1 & 36 & 100 & 1,287 & 0,886 \\
\hline Baik & 11 & 57,9 & 8 & 42,1 & 19 & 100 & $(0,413-4,01)$ & \\
\hline \multicolumn{9}{|l|}{ Umur } \\
\hline Dewasa & 23 & 52,3 & 21 & 47,7 & 44 & 100 & - & $0,01 *$ \\
\hline Lansia & 11 & 100 & 0 & 0 & 11 & 100 & & \\
\hline \multicolumn{9}{|l|}{ Jenis Kelamin } \\
\hline Laki-laki & 18 & 56,3 & 14 & 43,8 & 32 & 100 & 0,563 & 0,471 \\
\hline Perempuan & 16 & 69,6 & 7 & 30,4 & 23 & 100 & $(0,182-1,741)$ & \\
\hline \multicolumn{9}{|l|}{ Pendidikan } \\
\hline Rendah & 34 & 73,9 & 12 & 26,1 & 46 & 100 & - & $0,001 *$ \\
\hline Tinggi & 0 & 0 & 9 & 100 & 9 & 100 & & \\
\hline \multicolumn{9}{|l|}{ Pekerjaan } \\
\hline Tidak kerja & 20 & 87 & 3 & 13 & 23 & 100 & 8,913 & $0,03 *$ \\
\hline Kerja & 14 & 43,8 & 18 & 56,3 & 32 & 100 & $(2,113-34,763)$ & \\
\hline
\end{tabular}

Faktor internal adalah motivasi yang berasal dari dalam diri manusia, biasanya timbul dari perilaku yang dapat memenuhi kebutuhan sehingga tingkat kepuasan lebih maksimal. Disamping itu dari segi umur dan pekerjaan rata-rata pasien berumur dewasa dan mempunyai pekerjaan, sehingga dari dua hal tersebut pasien termotivasi ingin cepat sembuh.

Ada beberapa faktor yang mungkin mempengaruhi tidak ada hubungan antara dukugan keluarga dengan motivasi sembuh pada pasien TB paru, yaitu :

a. Pasien selalu mempunyai sikap positif, hal ini menunjukan adanya kepercayaan diri yang kuat, perencanaan diri yang tinggi serta selalu optimis dalam menghapi penyakitnya.

b. Kekuatan yang mendorong pasien itu sendiri, hal ini menunjukan bahwa timbulnya kekuatan akan mendorong seseorang untuk melakukan sesuatu, kekuatan ini berasal dari dalam diri individu serta keyakinan individu akan kekuatan kodrati.

2. Analisa pengaruh karakteristik demografi dengan motivasi untuk sembuh

a. Hubungan Usia Dengan Motivasi Untuk Sembuh

Pada tabel 3 menggambarkan bahwa dari 44 pasien TB paru yang berumur dewasa yang memiliki motivasi untuk sembuh yang tidak baik sebesar 52,3\%. Hasil presentase menunjukan bahwa antara pasien TB paru yang dewasa memiliki motivasi untuk sembuh yang baik dibanding dengan pasien TB paru yang Lansia. Hasil uji statistik didapatkan nilai p value $=0,01$ pada alpha $5 \%$, maka dapat disimpulkan bahwa terdapat hubungan yang bermakna antara umur responden dengan motivasi untuk sembuh pada pasien TB paru. 
Penelitian ini sesuai dengan teori Somantri 2009, bahwa penyakit TB paru dapat menyerang semua umur mulai dari anak-anak sampai dengan orang dewasa serta Lansia. TB anak dapat terjadi pada usia berapapun, namun usia paling umum adalah antara 1-4 tahun. Anak lebih sering mengalami TB luar paru-paru (extrapulmonary). Angka kejadian (prevalensi) TB paru pada usia 5-12 tahun cukup rendah, kemudian meningkat setelah masa remaja, dimana TB paru menyerupai kasus pada orang dewasa (sering disertai lubang/kavitas pada paru-paru). Sedangkan menurut Depkes 2009, sekitar 75\% pasien TB adalah kelompok usia yang paling produktif secara ekonomis (15-50 tahun). Diperkirakan seorang pasien TB dewasa, akan kehilangan rata-rata waktu kerjanya 3 sampai 4 bulan, hal tersebut berakibat pada kehilangan pendapatan tahunan rumah tangga sekitar 20-30\%.

b. Hubungan Jenis Kelamin Dengan Motivasi Untuk Sembuh

Pasien TB paru yang berjenis kelamin laki-laki memiliki motivasi untuk sembuh baik sebesar 43,8\%,

sedangkan jenis kelamin laki-laki yang mempunyai motivasi tidak baik sebesar 56,3. Hasil presentase menunjukan bahwa antara pasien TB paru yang berjenis kelamin laki-laki memiliki motivasi untuk sembuh yang baik dibanding dengan pasien TB paru yang berjenis kelamin perempuan. Hasil uji statistik didapatkan nilai $\mathrm{p}$ value $=0,471$ pada alpha $5 \%$, maka dapat disimpulkan bahwa tidak terdapat hubungan yang bermakna antara jenis kelamin responden dengan motivasi untuk sembuh pada pasien TB paru. Analisis keeratan hubungan antara dua variabel didapatkan nilai OR =0,563 (95\% CI : 0,182 1,741) artinya pasien TB paru yang berjenis kelamin laki-laki berpeluang 0,710 kali untuk memiliki motivasi yang baik dibanding dengan pasien TB paru yang berjenis kelamin perempuan.

Menurut WHO (2010), jumlah penderita TB Paru laki-laki hampir dua kali lipat dibandingkan jumlah penderita TB Paru pada wanita, yaitu $42,34 \%$ pada laki-laki dan $28,9 \%$ pada wanita. TB paru Iebih banyak terjadi pada laki-laki dibandingkan dengan wanita karena laki-laki sebagian besar mempunyai kebiasaan merokok sehingga memudahkan terjangkitnya TB paru.

Hasil analisis bivariat menunjukan bahwa tidak ada hubungan antara jenis kelamin dengan motivai untuk sembuh pada pasien TB paru di Puskesmas Kecamatan Kronjo, dengan $\mathrm{p}$ value $=0,811$. Ketidakbermaknaan hasil ini dimungkinkan karena motivasi untuk sembuh pada pasien TB paru tidak hanya dilihat dari jenis kelamin saja tetapi dapat dilihat dari faktor lain seperti tingkat sosial ekonomi, karena walaupun saat ini pengobatan TB di gratiskan oleh pemerintah tetapi kalau jarak tempuh dari rumah ke tempat pengobatan cukup jauh dan membutuhkan transportasi yang cukup mahal, kemungkinan penderita TB tidak akan melakukan pengobatan.

\section{c. Hubungan Pendidikan Dengan Motivasi Untuk Sembuh}

Pasien TB paru yang berpendidikan rendah memiliki motivasi untuk sembuh yang tidak baik sebesar $73, \%$, dan pendidikan rendah yang mempunyai motivasi yang baik sekitar $26,1 \%$. Hasil presentase menunjukan bahwa antara pasien TB paru yang berpendidikan rendah memiliki motivasi untuk sembuh yang tidak baik dibanding dengan pasien TB paru yang berpendidikan rendah memiliki motivasi baik. Hasil uji statistik didapatkan nilai $\mathrm{p}$ value $=0,001$ pada alpha 5\%, maka dapat disimpulkan bahwa terdapat hubungan yang bermakna antara pendidikan responden dengan motivasi untuk sembuh pada 
pasien TB paru.

Hasil penelitian ini sesuai dengan Yunie dkk (2012) dan penelitian Sitepu (2009), Tingkat pendidikan sangat berpengaruh terhadap kemampuan penderita untuk menerima informasi tentang penyakit, terutama TB paru. Kurangnya informasi tentang penyakit TB paru menyebabkan kurangnya pengertian pengetahuan terutama mengenai dampak terhadap orang lain, terutama keluarga yang ada di rumah

F. Hubungan Pekerjaan Dengan Motivasi Untuk Sembuh

Pasien TB paru yang bekerja memiliki motivasi untuk sembuh yang baik sebesar 56,3\%. Hasil presentase menunjukan bahwa antara pasien TB paru yang bekerja memiliki motivasi untuk sembuh yang baik dibanding dengan pasien TB paru yang tidak kerja. Hasil uji statistik didapatkan nilai p value $=0,03$ pada alpha 5\%, maka dapat disimpulkan bahwa terdapat hubungan yang bermakna antara pekerjaan responden dengan motivasi untuk sembuh pada pasien TB paru. Analisis keeratan hubungan antara dua variabel didapatkan nilai $\mathrm{OR}=8,571(95 \% \mathrm{CI}: 2,113-34,763)$ artinya pasien TB paru yang bekerja berpeluang 8,571 kali untuk memiliki motivasi yang baik dibanding dengan pasien TB paru yang tidak bekerja.

Hasil penelitian ini sesuai dengan penelitian Sitepu (2009) menyatakan bahwa responden yang terbanyak adalah mempunyai pekerjaan. Depkes (2010) Jenis pekerjaan menentukan faktor risiko apa yang harus dihadapi setiap individu. Bila pekerja bekerja di lingkungan yang berdebu paparan partikel debu di daerah terpapar akan mempengaruhi terjadinya gangguan pada saluran pernafasan. Paparan kronis udara yang tercemar dapat meningkatkan morbiditas, terutama terjadinya gejala penyakit saluran pernafasan dan umumnya TB Paru. Jenis pekerjaan seseorang juga mempengaruhi terhadap pendapatan keluarga yang akan mempunyai dampak terhadap pola hidup sehari-hari diantara konsumsi makanan, pemeliharaan kesehatan selain itu juga akan mempengaruhi terhadap kepemilikan rumah (kontruksi rumah). Kepala keluarga yang mempunyai pendapatan dibawah UMR akan mengkonsumsi makanan dengan kadar gizi yang tidak sesuai dengan kebutuhan bagi setiap anggota keluarga sehingga mempunyai status gizi yang kurang dan akan memudahkan untuk terkena penyakit infeksi diantaranya TB Paru. Dalam hal jenis kontruksi rumah dengan mempunyai pendapatan yang kurang maka kontruksi rumah yang dimiliki tidak memenuhi syarat kesehatan sehingga akan mempermudah terjadinya penularan penyakit TB Paru

\section{KESIMPULAN DAN SARAN}

Peneliti menyimpulkan bahwa motivasi kesembuhan seorang pasien bukan saja dari dukungan keluarga tetapi kekuatan yang berasal dari dalam diri individu pasien itu sendiri, yang mendorong, membangkitkan, menggerakkan, melatarbelakangi, menjalankan dan mengontrol seseorang serta mengarahkan pada tindakan penyembuhan atau pulih kembali serta bebas dari suatu penyakit yang telah dideritanya selama beberapa waktu dan membentuk keadaan sejahtera dari badan, jiwa dan sosial yang memungkinkan seseorang hidup produktif secara sosial dan ekonomi. Saran dari hasil penelitian ini untuk keluarga maupun pihak yang terkait lebih dapat meningkatkan faktor dari dalam diri pasien seprti meningkatkan taraf pendidikan, meningkatkan pengetahuan 
pasien tentang TB paru dan penyediaan layanan pekerjaan karena hal tersebut merupakan faktor utama yang dapat memunculkan motivasi kesembuhan pada pasien yang mengalami TB paru.

\section{DAFTAR PUSTAKA}

1. Bruce Nigel, et al (2008), Quantitative Methods for Health Research a Practical Interactive Guide to Epidemiology and Statistics, John Wiley \& Sons, Ltd : Chichester, England

2. Budiarto Eko (2012), Metodologi Penelitian Kedokteran : Sebuah Pengantar, Jakarta: Penerbit Buku Kedokteran EGC

3. Dahlan Sopiyudin (2012), Langkah-langkah Membuat Proposal Penelitian Bidang Kedokteran dan Kesehatan, Sagung Seto : Jakarta

4. Departemen Kesehatan (2010), Hasil Riskesdas 2010, www. Litbang.depkes.go.id, diakses tanggal 4 April 2013

5. Departemen Kesehehatan (2009), Pedoman Penanggulangan Tuberkulosis (TB), Depkes : Jakarta

6. Dharma.K.K (2011), Metodologi Penelitian Keperawatan. CV. Trans Info Media : Jakarta

7. Doenges. E. Marily, et al (2010), Rencana Asuhan Keperawatan, Edisi 3, Penerbit Buku Kedokteran : Jakarta

8. Friedman M. Marilyn, et al (2010) Buku Ajar Keperawatan Keluarga Riset, Teori dan Praktik, Penerbit Buku Kedokteran EGC :Jakarta

9. Hastono, S.P (2007), Analisis Data Kesehatan. Fakultas Kesehatan Masyarakat Universitas Indonesia : Jakarta

10. Hidayat. A. A. A (2007), Riset Keperawatan dan Teknik Penulisan Ilmiah, Salemba Medika : Jakarta

11. Hutape (2006), Pengaruh Dukungan Keluarga Terhadap Kepatuhan Minum Obat, Surabaya, Tidak dipublikasikan

12. Iryani Ade (2007), Motivasi Sembuh pada Pengguna Napza, www. Gunadarma.ac.id. diakses tanggal 14 Oktober2013

13. Kementerian Kesehatan RI Direktorat Jenderal Pengendalian Penyakit dan Penyehatan Lingkungan (2011), Strategi Nasional Pengendalian TB di Indonesia 2010-2014,Kemenkes

14. Media Yulfira (2011), Pengetahuan, Sikap dan Perilaku Masyarakat Tentang Penyakit Tuberkulosis (TB) Paru di Kecamatan Sungai Tarab, Kabupaten Tanah Datar Propinsi Sumatera Barat, Media Penelitiandan Pengembangan Kesehatan, Vol. 21, No. 2 Juni 2011.www.ejurnal.litbang.depkes.go.id. Diakses tanggal 16Mei 2013

15. Musadad Anwar (2006), Hubungan Faktor Lingkungan Rumah dengan Penularan TB Paru Kontak Serumah, Jurnal Ekologi Kesehatan, Vol. 5, No. 3 Desember. www.ejurnal.litbang.depkes.go.id. Diakses tanggal 5 Mei2013

16. Muttaqin Arif (2008), Buku Ajar Asuhan Keperawatan Klien dengan Gangguan Sistem Pernapasan, Jakarta : Salemba Medika

17. Nasehudin T, S dan Gozali Nanang (2012), Metodologi Penelitian Kuantitatif,Penerbit Pustaka Setia : Bandung 
18. Niven Neil (2002), Psikologi Kesehatan, Pengantar untuk Perawat dan Profesional Kesehatan Lain, Edisi 2, Penerbit Buku Kedokteran EGC : Jakarta

19. Notoatmodjo, S (2002). Metodologi Penelitian Kesehatan. Jakarta. Rineka Cipta Nursalam (2008), Konsep dan Penerapan Metodologi Penelitian Ilmu Keperawatan,Pedoman Skripsi, Tesis dan Instrumen Penelitian Keperawata. SalembaMedika Jakarta

20. Perry and Potter (2002), Clinical Nursing Skilla and Techniques, 5th, Mosby, Philadelphia

21. Rachmawati Tety (2009), Pengaruh Dukungan Sosial dan Pengetahuan tentang Penyakit TB terhadap Motivasi untuk Sembuh Penderita Tuberculosis Paru yang Berobat Di Puskesmas. Tidak Dipublikasikan

22. Ratnasari Nita Yunianti (2012), Hubungan Dukungan Sosial dengan Kualitas Hidup pada Penderita TB Paru di Balai Pengobatan Penyakit Paru Yogyakarta Unit Minggiran, Jurnal Tuberkulosis Indonesia, Vol. 8 - Maret 2012

23. Salama Ngabila (2017), Beban Tuberkulosis (TB) di Jakarta Timur, Kompasiana, Jakarta

24. Sastroasmoro Sudigdo dan Ismael Sopyan (2011), Dasar-dasar Metodologi Penelitian Klinis, Edisi 4, Jakarta : Sagung Seto

25. Smeltzer, S and Bare (2008), Brunner and Suddarth's Texbook of Medical Surgical Nursing, Philadelphia : Lippincott

26. Soetjiningsih (2004), Tumbuh Kembang Anak, Penerbit Buku Kedokteran EGC : Jakarta

27. Somantri Irman (2009), Asuhan Keperawatan pada Klien dengan Gangguan Sistem Pernapasan, Edisi 2, Jakarta : Salemba Medika

28. Stanhope Marcia and Knollmueller (2010), Praktik Keperawatan Kesehatan Komunitas, Edisi 2, Penerbit Buku Kedokteran : Jakarta

29. Sugiyono (2009), Statistika untuk Penelitian.Edisi 5.Bandung : Alfabeta Sukandarrumidi (2006), Metodologi Penelitian : Petunjuk Praktis Untuk PenelitiPemula, Gadjah Mada University Press : Yogyakarta

30. Suhardi (2013), The Science of Motivation, Kitab Motivasi, PT. Gramedia : Jakarta

31. Sunarto Kamanto (2004), Pengantar Sosiologi, Edisi Revisi, Jakarta : Penerbit Fakultas Ekonomi Universitas Indonesia

32. Susilo, WH (2013), Prinsip-prinsip Biostatistik dan Aplikasi SPSS Pada Ilmu Keperawatan, In Media, Jakarta

33. Susilo, WH dan Aima MH (2013), Penelitian dalam Ilmu Keperawatan Pemahaman dan Penggunaan Metode Kuantitatif Serta Aplikasi dengan Program SPSS dan Lisrel, In Media, Jakarta

34. Susilo, WH dan Aima MH (2013), Skala Pengukuran dan Instumen Penelitian Aplikasi SPSS pada Penelitian Ilmu Keperawatan, In Media, Jakarta

35. Suyono Slamet (2004), Buku Ajar Ilmu Penyakit Dalam, Jilid II, Edisi 3, Balai Penerbit FKUI : Jakarta

36. Sutarna Agus, et al (2007), Buku Ajar Keperawatan Komunitas Teori Praktek, Edisi 3, Penerbit Buku Kedokteran EGC : Jakarta

37. WHO (2010), Global Tuberculosis Control Report 2010, www.who.int/tb/country/en/index.html. Diakses Tanggal 3 April 2013 
38. Yahmin Setiawan (2012), TB Paru Masalah Kesehatan Dunia dan Indonesia, http://www.lkc.or.id/2012/03/21/tb-masalah-kesehatan-dunia-indonesia/, Diakses tanggal 03 April 2013

39. Yunie, et al (2012), Hubungan antara pengetahuan, sikap pasien dan dukungan keluarga dengan kepatuhan minum obat pada pasien TB paru di BKPM Pati. Jurnal Ilmu Keperawatan dan Kebidanan. Vol. 1. 